\section{ÉRKEZIK-E A VARSÓI GYORS?}

Holtzer Péter (A szerző nyugdijszakértö, a Világbank és az IMF külső konzulense. 2007-10 között a Nyugdij és Idöskor Kerekasztal elnöke volt.

\section{ÖSSZEFOGLALÓ}

Lengyelországban új törvényt fogadtak el a foglalkoztatói nyugdíjalapokról. ${ }^{1} 2019$ és 2021 között fokozatosan épül ki az a rendszer, amely szerint a foglalkoztatottak automatikusan kerülnek be a munkáltató által kötelezően nyújtandó nyugdíjalapba, azonban önkéntes döntésük alapján kiléphetnek belőle. Ez utóbbi esetben nem kerül a bérükből automatikusan levonásra a tagdíj, nem jutnak a munkáltató és az állam által nyújtott kiegészítő támogatáshoz, és ebben a formában nem takarítanak meg nyugdíjcélokra. A cikk a korábbi hasonló reformok tapasztalatait, a szabályozás lehetséges buktatóit mutatja be, és azt, hogy régiónkban milyen szempontokra érdemes még odafigyelni.

\section{SUMMARY}

A new law on employer-sponsored pension plans has been passed in Poland. The system will be rolled out between 2019 and 2021 where employees will automatically become members of a pension plan to be provided by the employer but from which the workers are allowed to opt out. In this case, their individual contribution is not deducted from wages, and employees also renounce their right to the matching contributions from the employer and the state, thus they do not save this way for pensions. The article describes the experience of similar previous reforms and the potential pitfalls of regulation, and draws attention to other aspects relevant in our region.

Kulcsszavak: foglalkoztatói nyugdíj, nyugdíj

Keywords: occupational pension, pension

JEL: E21, E22, G28, H55

DOI: $10.18530 /$ BK.2018.4.14

http://dx.doi.org/1018530/BK.2018.4.14
Lengyelországban a közelmúltban elfogadásra került egy törvény, amely a kváziönkéntes foglalkoztatói nyugdíjalapok rendszerét vezeti be. ${ }^{2}$ A munkáltatók kötelesek lesznek dolgozóikat automatikusan beléptetni egy nyugdíjcélú megtakarítási rendszerbe, akik azonban önkéntes döntéssel kiléphetnek onnan, ám ekkor nem részesülnek a munkáltató és az állam kiegészítő támogatásából.

A lengyel rendszer 2019 és 2021 között fokozatosan épül majd ki a nagyobb munkáltatóktól kezdve a kisebbek felé. Ha a munkavállaló szabad döntése alapján kilép a rendszerből, négyévente meg kell erösítenie ezt a szándékát, különben újra életbe lép az automatikus beléptetés. A munkavállalótól nettó bére 2 százalékát vonják le (amelyet 4 százalékig megemelhet). Ehhez a munkáltató 1,5 százalék kiegészítést kell, hogy adjon, és ezt szintén 4 százalékig kiegészítheti. Az állam pedig fix összegü évi 240 złoty (kb. 18 ezer forint) támogatást ad (ez a nettó éves átlagbér hozzávetőlegesen 0,7 százaléka), amelyet kiegészít egy „,welcome bónusz" 250 złoty a belépéskor. A dolgozó a támogatásokat adómentesen kapja, míg a munkáltató oldalán kedvezményesen figyelembe vehető és adóalapot csökkentő a támogatás. A munkáltató az opcionálisan adható kiegészítések terén differenciálhat munkavállalói között (pl. munkakör vagy a cégnél eltöltött idő szerint), ahogy az foglalkoztatói nyugdíjalap esetén szokásos.

A kváziönkéntes (,auto-enrolment”) rendszer az elmúlt egy-két évtized egyik legfontosabb innovációja a nyugdíjcélú megtakarítások terén. Megközelítésében a kötelező („2. pillér”) és az önkéntes („3. pillér”) közé helyezhető, nem kötelezi a dolgozót semmire, viszont sokkal könynyebbé teszi számára az előtakarékosság megkezdését, eközben azonban a munkáltatót kötelezi a rendszerben való részvételre, a dolgozók támogatására. A sikeres példák azt mutatják, hogy az önkéntes megtakarítási rendszerekben tapasztalható 10-20 százalékos lefedettség akár 70-90 százalékosra is nőhet ebben a konstrukcióban, mivel az egyénnek semmit nem kell tennie a részvételhez, miközben a kilépés aktív, tudatos lépéseket igényelne. Mindezek mellett a munkavállaló még pótlólagos támogatásokat is kap, a nettó béréből levont pár százalékot pedig esetleg meg sem érzi. Néhány ország (elsőként Új-Zéland, majd az Egyesült Királyság) már bevezette ezt a rendszert, egyre népszerübbek az Egyesült Államok vállalati nyugdíjprogramjain (401(k)) belül is, és az elmúlt időszakban elkezdődtek az első kísérletek a legfejlettebb országok körén kívül. Törökország 2017 elején vezetett be egy új rendszert, amelyet most Lengyelország követ. Grúzia sokáig készített elő hasonló reformot, majd végül mégis egy kötelező rendszer mellett döntött.

Ebben az írásban nem célom a kváziönkéntes rendszer megközelítésének általános, illetve az új lengyel szisztémának a részletesebb bemutatása. Az utóbbiról egyelőre nem tudunk többet, és menet közben fog kiderülni, hogy mennyire lesz sikeres. A kváziönkéntes rendszerrel kapcsolatban pedig nemrég készítettem egy összefoglalást. ${ }^{3}$ Ez utóbbi alapján arra térek ki ezúttal, hogy az új lengyel törvény (illetve valamelyest a már működő törökországi gyakorlat) milyen következtetések levonását segítheti abban a kérdésben, hogy ez a „nyugatról” származó újítás mennyiben válhat sikeressé „keleten” is. 


\section{Munkaerőpiaci informalitás}

Lengyelországot, Magyarországot, Törökországot és a legtöbb felzárkózóban lévő országot jellemzi a nyugatinál jelentősen magasabb munkaerőpiaci informalitás, a szürke- és feketegazdaság relevanciája. Az adó- és járulékbehajtás hatékonysága nyilván valamelyest javulni tud idővel, de a „minimálbérre bejelentés”, a zsebbe fizetés és hasonlók még az elektronikus számlázások és bekötések mellett is jelentősek maradnak. Ebből fakadóan sokan csak a valós jövedelmük töredéke után tesznek félre, ha be is kerülnek, és bent is maradnak egy hivatalos megtakarítási rendszerben. Másrészt igaz, hogy a legtöbb szabályozásban megjelenik a büntetés fenyegetése a munkáltató felé, ha megpróbálja kényszeríteni („ösztönözni”) a dolgozót arra, hogy ne maradjon a rendszerben, és így ne kérje a munkáltatói támogatást. A valóságban azonban kérdéses, hogy - különösen a mikroméretű vállalkozások esetében - ezen szankciók érvényesítése mennyire lehet reális.

A kötelezö és az önkéntes nyugdípénztár esetében is tanulság, hogy azok, akik egyébként nem nagyon jelennek meg a hatóságok radarernyöjén hivatalosan bevallott érdemleges méretü jövedelemmel, nem fogják csak azért feladni ezt a státuszt, hogy transzparens formában elkezdjenek nyugdíjra előtakarékoskodni, és kapjanak némi kedvezményt mellé. Ez így összességében túl drága lenne számukra. Tehát fel kell készülni arra, hogy első körben a foglalkoztatói nyugdíjalap is föképp azokat éri el, mint az eddigi pillérek (ideértve a társadalombiztositást is): akiknek formálisan bejelentett, járulékfizetéssel járó állásuk van. Utána lehet azon dolgozni majd, hogy az informális szektor számára is létezik-e olyan egyszerű módszer a belépésre, amely számukra megéri ezt.

Ugyancsak utána, illetve párhuzamosan lehet és kell majd a rendszerből kimaradó tartósan leszakadók kérdésére valamilyen választ adni, akik nem ,jókedvükből” megkerülők, hanem mert gyakorlatilag nem képesek érdemben a munkaerőpiacon megkapaszkodni. Szép szokás és hagyomány bünösként mutogatni rájuk ebben a kérdésben, de attól még, hogy a mindenkori oktatási rendszer (valamint szociális és egészségügyi rendszer stb.) nem segít az egymást követő generációk felemelésében, továbbra is releváns kérdés, hogy a nyugdíjrendszernek van-e, lesz-e dolga azokkal, akiknek időskorukban sincs semmilyen jövedelmük. Azaz egy foglalkoztatói nyugdíjalap-szisztéma kiépítése sem ad választ arra, hogy „nulladik pillérről”, alapnyugdíjról semmilyen elgondolás nincs, túl azon, hogy ez itt és most nem téma.

\section{A munkáltató együttmüködési készsége}

A hagyományos foglalkoztatói nyugdíjalapnak - ahol a munkáltató jogszabályi kötelezés nélkül is ad kiegészítő nyugdíj-előtakarékossági támogatást dolgozóinak - eddig nemigen volt kultúrája Magyarországon, pedig az ezt elvileg elősegítő törvény már több mint tízéves (még ha az európai irányelv akkori átültetése talán nem is a legszerencsésebben valósult meg). A közterhek így is magasak, és a cégek nemigen akarták még drágábbá tenni a foglalkoztatást, egyáltalán nem gondolták azt, hogy még többet fizetnének a dolgozók nyugdíj-előtakarékosságára, miközben már így is sokat fizetnek az államnak. Az a nyugati országokban - elsősorban Hollandiában és Dániában, de másutt is - régóta kialakult együttmüködés, amelyben bevett gyakorlat, elvárás a munkáltató által nyúitott ilyen csomag, még ha az nem is törvényileg kötelezően előírt, régiónkban sosem volt jellemző. Ebben a tekintetben is érdekes kérdés az előbb említett fenyegető büntetés a munkáltató felé arra az esetre, ha kiléptetné dolgozóját a rendszerből. Illetve általánosabban: érdekes lenne tudni, hogy a lengyel munkáltatók, az ő kamaráik, szervezeteik milyen lelkesedéssel fogadták az új szabályt a kötelező munkáltatói hozzájárulás-fizetésről. ${ }^{4}$

Mostanában azonban két szempontból is változóban lehet a munkáltatói hozzáállás a korábbi évekhez képest. Egyrészt csökkennek a járulékok. Másrészt pedig munkaerőhiány alakult ki, azaz akár fel is értékelődhet a kis pluszban adott támogatás a dolgozói lojalitásért folyó versenyben. Manapság tehát reálisabb lehet a munkáltatókkal történő ilyen megegyezés, tehermegosztás.

Persze ezzel éppen szembemenni látszanak a hazai adóváltozások. A munkáltató által adható támogatások hosszú idő óta tartó adókedvezmény-csökkenése most érte el azt a pontot, hogy 2019-től már gyakorlatilag semmi nem adható a bérnél „olcsóbban” a dolgozónak, így például az önkéntes pénztári támogatás sem. Ez egyébként hosszú idő óta nyomon követhető a pénztári befizetések trendjében is, ahol folyamatosan csökkent a munkáltatói tagdíj-hozzájárulás mértéke. ${ }^{5}$ Ha a kváziönkéntes logikájú foglalkoztatói nyugdíjalapoknak itthon is fontos teret kívánna adni a szabályozó, akkor nyilvánvalóan a munkáltatói befizetéseket némileg segíteni, ösztönözni érdemes majd ismét, ahogy azt a lengyel példa is mutatja.

Érdemes egyébként kitérni a török reform egyik eddigi kudarcára. A törvényelökészítés 2014-16-ban zajlott, ennek alapján 2017 elején indult el az új rendszer. Az első tapasztalatok (és ezek még bőven a török gazdaság és piacok idei évi teljes fejreállása előttről származtak) azt mutatták, hogy a kilépési hányad (tehát az automatikus beléptetés után mégis kilépők aránya) a sikeres reformok alacsony, 5-10 százalékos adatával ellentétben meghaladta a 40 százalékot is. Ennek számos oka lehet (általános bizalmatlanság, szabályozási hibák), de az egyik biztosan az, hogy a munkáltató végül nem fizet kötelezően hozzájárulást. A nagy török munkáltatói csoportok, holdingok híresen meghatározóak a gazdasági-politikai közegben, és a törvényelökészítés nem bizonyult elég erősnek ahhoz, hogy kötelezze őket 2-3 százalékos kiegészítő hozzájárulásra. Így pedig a munkavállaló számára is kevésbé vonzó a befizetés (csak egy nem túl magas állami jóváírást kapna a nettó bérlemondás ellenében). Ez hasznos tanulság minden, hasonló reformot tervező ország számára. 


\section{A tagdij mértéke}

Lehetetlen pontos számot mondani arra, hogy mégis „mennyit kell félretenni” nyugdíjcélokra, még ha ez is az első kérdés minden vonatkozó beszélgetés során. A válasz nagyon sok mindentől függ, és ezek közül csak egy az, hogy mégis mit feltételezünk az állam nyugdíjkifizetési képességéről, amikorra mi majd elérünk oda. Egyéni élethelyzet, befektetési hozamvárakozások, nyugdíjba meneteli korra és várható élettartamra vonatkozó becslések és sok minden más teszi mindezt igen bizonytalanná.

Mindezzel együtt az én válaszom az szokott lenni, hogy a havi bér inkább 15, mint 10 százalékának félretétele - és értelmes, hosszú távú befektetése - lehet az az összeg, amely mellett már nyugodtabbak lehetünk. Mindezt persze fiatalkortól kezdve, és nem ötvenévesen észbe kapva.

\section{Az államnak különös felelössége van a default (automati- kusan követett) tagdíjszintek meghatározásával, illetve a kommunikációval.}

Ezt a szintet jellemzően nem szokták elérni a kváziönkéntes megtakarítási rendszerek, azok legtöbbször tíz százalék alatt maradnak. Ezt a lengyel példa is illusztrálja, ahol a minimumot követve kb. 4 százalékot, de még az opcionális kiegészítésekkel is 9 százalékot fizetne be együtt a három szereplö: dolgozó, cég és állam.

Azállamnak különös felelőssége van a default (automatikusan követett) tagdíjszintek meghatározásával, illetve a kommunikációval. Mivel az egész innováció arra alapul, hogy az egyénnek semmit nem kell csinálnia, vele csak megtörténnek a dolgok, és a végén jó lesz („,libertariánus paternalizmus"), értelemszerüen azt is fogja feltételezni, hogy ez így akkor elég is, és minden probléma megoldódott. Márpedig valószínúleg nem: a bér néhány százalékát befizetve, befektetve, különösen akkor, ha csak az életpálya során később kezdi, vagy megszakítások vannak benne, nem fogja elérni a várhatóan csökkenő állami nyugdíjszintek mellett azt a teljes időskori jövedelmet, amelyet feltételez. Ekkor pedig ki lesz az egyén szemében a hibás? Az állam, a szabályozó.

Természetesen ezt tudják is ott, ahol már működik egyideje a rendszer. Nagy-Britanniában például, ahol összesen 8 százalék kerül befizetésre (ez is fokozatosan növekedett idáig az elmúlt években), már évek óta tudja a szakma, hogy előbb-utóbb elő kell majd venni a további emelés kérdését, csak előbb épüljön ki teljesen a rendszer, szokja meg minden szereplő. Az Egyesült Államok vállalati nyugdíjalapjainál pedig egyre gyakrabban müködik az a megoldás is, amely az éves béremelések esetén a növekmény egy részét a nyugdíjszámlára tereli át, ezzel úgy emelve a befizetéseket, hogy azt a dolgozó észre sem veszi (egy kicsit kevesebb béremelést kap kézhez, mint amúgy kapott volna).
Nem lehet ajtóstul rontani a házba, és induláskor magas befizetési hányadot írni elő a munkavállalónak és munkáltatónak, mert akkor nem lesz siker, nem fognak a rendszerben maradni a dolgozók. Érdemes azonban a reformot úgy tervezni, hogy egy ilyen típusú második lépés, fokozatosság 5-10 éven belül megtörténhessen.

\section{Más célokra történő számlahozzáférés}

Az új lengyel szabályozás szerint a számlaegyenleget a megtakarítási időszakban részben házvásárlási bankkölcsön saját erejének biztosítására is lehet majd fordítani, és vis maior esetben (pl. súlyos betegség) is részben hozzáférhető. Számos szempont befolyásolja az ilyen kivételek lehetővé tételét a jogszabályban.

A termék eladása szempontjából természetesen segít, ha a megtakarító tudja, hogy valamennyire (időlegesen vagy részben akár végleges kivonással, teljesen vagy részlegesen, adómentesen vagy leadózva) hozzá tud férni a pénzhez, ha nagy szüksége van rá, vagy amikor még más célok életbevágóbbak lehetnek. Ezért erős a késztetés a minél lazább hozzáférési szabályokra.

Ezzel szemben áll azonban az az érv, hogy ha nyugdíjcélú megtakarításokra létrehozott termékekből túl sok pénzkivétel történhet idejekorán, akkor sokkal kevésbé sikerül érdemi válaszokat adni a nyugdíjinanszírozási problémákra, ami a jogalkotó eredeti szándéka. Az Egyesült Államok vállalati nyugdíjalapjaiból származó tapasztalat például, hogy akár 40 százalékot is elérhet a „szivárgás”, a más célra történt igénybevétel, azaz minden befizetett dollárból rossz esetben csak 60 cent ér célba végül nyugdíj-kiegészítésként.

Ugyancsak fontos, bár ritkán vizsgált szempont az is, hogy mindez a befektetések hatékonyságát is befolyásolhatja. Teljesen másképp lehet a vagyonkezelés stratégiájáról és gyakorlati megvalósításáról beszélni, ha csak befizetésekkel kell számolni (a nyugdíjszolgáltatásig), illetőleg ha előre nehezen tervezhető, de idő előtti, akár jelentős mértékű kifizetésekkel is kell számolni. Az ilyen, a nyugdíjmegtakarítás szempontjából irreleváns és zavaró likviditási igény értelemszerủen rongálja a hosszú távra tervezhető hozam-kockázat pályát.

Ezek azok a szempontok, amelyek miatt lehetőleg érdemes minimalizálni, nehézzé tenni, esetleg teljesen kizárni azt, hogy megtakarítási célok egy termékben keveredjenek. Továbbá ennek orvoslására merülnek fel olyan gondolatkísérletek is, mint például egy termékbe kombinálni egy nyugdíj- és egy házvásárlási előtakarékossági intézményt, de két elkülönített alszámlára, ahol ha a lakás-előtakarékossági számlaegyenleget a megtakarító nem (vagy nem teljes mértékben) veszi igénybe, az lehessen majd átcsoportosítható a nyugdíj célokra, de a másik irányba ne történhessen mozgás. 


\section{Nyugdíjszolgáltatás}

Az újonnan születő nyugdíjmegtakarítási rendszerek, reformok esetében sokszor nem túl erős a nyugdíjszolgáltatás szabályozása - „Ej, ráérünk arra még” megközelítéssel. Emlékezhetünk, hogy a magyar magánpénztári rendszerben sem volt ez soha rendesen megoldva, és mielött nyoma veszett volna az egésznek, éppen erre is tett volna egy elkésett kísérletet a 2009-es kormány.

A szakma, a szabályozó állandó vitája, hogy bele kell-e kényszeríteni a megtakarítókat az élethosszig tartó járadékba.

A lengyel foglalkoztatói nyugdíjalapokról szóló törvény sem bonyolítja túl a kifizetési szakasz szabályozását. A megtakarítások 25 százalékát egy összegben, 75 százalékát pedig legalább tízéves (120 hónapos) részletekben hívhatja le a megtakarító. Valódi életjáradékról nem beszél a jogszabály.

A szakma, a szabályozó állandó vitája, hogy bele kell-e kényszeríteni a megtakarítókat az élethosszig tartó járadékba (annak különbözö lehetséges variációival persze), mert különben korán felélik a vagyont, és aztán visszahull a problémájuk a szabályozóra. Avagy felnőttnek kell őket tekinteni, kellő információval ellátni mindenkit, és segíteni a döntésekben, de azután magukra kell őket hagyni. Mindezt úgymond azért is, mert a nyugdijbiztosítási termékek, életjáradékok még a legnagyobb piacokon is sokszor drágák, ezért nem lehet az embereket kötelezni ilyen termékek vásárlására. Emlékezetes módon néhány éve a brit szabályozás fordult hirtelen 180 fokot a kötelezéstôl a szabadság irányába - és azóta is folyamatosan vitázik a szakma, a szakértők, a szabályozók, a fogyasztóvédők arról, hogy jobban jöttek-e ki az ügyfelek, boldogabbak-e, meg lettek-e vezetve, és így tovább.

A megengedés vagy kötelezés dilemmájára adott válasz nyilván erősen függ attól is, hogy mekkora részét teszi ki ez az előtakarékossági csatorna a tervezett időskori jövedelemnek. Ha csak egy kisebb kiegészítés, akkor könnyebb azt mondani, hogy az egyén szabadon rendelkezzen a megtakarított összeggel. Ha azonban jelentős mértékben egészíti ki és helyettesíti a központi állami gondoskodást, akkor alaposabb megfontolást igényel. Az állam képessége a magasabb helyettesítési ráták fenntartására a lengyel esetben is romlani fog. Így, ha siker lesz a foglalkoztatói nyugdíjalapokból, és látszani fog a következő egy-két évtizedben, hogy sokaknak jelent majd egyre jelentősebb kiegészítést, akkor egyrészt nyilván nagyobb erővel fordul a biztositói szektor az ügyfelek felé, másrészt a döntéshozók is szükségét érzik majd, hogy szabályozzák a piacot, a termékeket. További szempont, hogy ha az állam érdemi támogatást ad a megtakarításokhoz, akkor erösebb érvek szólhatnak a legalább részleges kötelezés mellett. Mindezeket figyelembe véve talán majd várható lesz valódi életjáradékok megjelenése, részleges előírása a jövőben a lengyel foglalkoztatói nyugdíjalapok esetében is.

\section{A magyar csodafegyver?}

Évek óta fel-felreppennek ötletek a gyermeknevelés és a nyugdíj összekötéséröl. Ezek néha felhangosodnak, és el is érik a sajtó szintjét, máskor csak búvópatakként csordogálnak. Időről időre azt is hallani, hogy „holnap” történik valami komoly bejelentés a tárgyban. De eddig mindenesetre nem. ${ }^{6}$

A kérdésfelvetés persze jogos. Egyrészt nem születik elég gyerek, és ez a nyugdíjproblémák egyik, még ha messze nem is egyetlen oka. Az alacsony gyerekszám természetesen nem is csak a nyugdíjkérdéseket súlyosbítja. Másrészt, aki gyermeket nevel, annak nagyon sok olyan költsége van (ideértve a munkából kiesett időt is), ami a gyermeket nem vállalónak nincs, és ezt valahol díjazni lehetne intergenerációs megközelítésben.

Az eddig született válaszkísérletek azonban nem túl biztatók. Általános nemzetközi megfigyelés, hogy a pronatalista célokat nem is annyira az egyszerü pénzbeli támogatások segítik, mint inkább ezek kombinálása például a nők gyermekszülés utáni munkaerőpiaci visszatérésének segítésével, bölcsőde-óvoda infrastruktúrával, a nők és férfiak közti tehermegosztás ösztönzésével (pl. a gyermekvállalási támogatás egy része csak akkor jár, ha az apa van otthon) és egyéb okoseszközökkel. Másrészt az a specifikus megközelítés, hogy a ma egy további gyermeket vállaló avagy nem vállaló szülők számára vonzó és egyben hiteles szempont az, hogy majd harminc-negyven év múlva ettől több nyugdíjat fizet nekik az állam, nem tűnik reálisnak.

Ezért is érdekesek egyes, magánbeszélgetésekben nemrégiben hallott, hivatalosan meg nem erösített hírek. Eszerint esetleg elképzelhető lenne a kváziönkéntes rendszer olyan megvalósítása Magyarországon, ahol a számlán jóváíródó állami támogatás csak akkor kerül az egyenleg többi részével kifizetésre, ha igénybevételkor a tulajdonos igazolni tudja a megkívánt számú (mondjuk kettő) gyermek születését. Semmilyen részletet nem ismerve nem tudhatjuk, hogy valóban létezik-e ilyen titkos előkészítő munka, és hogy az milyen részletezettségű lenne (például: csak egy gyerek vállalása az állami számlajóváírásokat részben adóztatná vissza, míg három gyerek valami extra bónusszal járna). Az is nyilvánvalónak tűnik, hogy bármilyen kísérlet arra, hogy a megszült gyermekek „minőségét” is figyelembe vegye - egyáltalán megélte-e az aktív kort, és „fegyelmezetten” beállt a közteherviselők sorába, avagy elcsatangolt bárány lett belőle, nem lett-e beteg, stb. - már vállalhatatlan súlyú kérdéseket vetne fel. Mindettől függetlenül a gyermekvállalás és a nyugdíjkifizetések összekötésének ez akár egy plauzibilisebb terve is lehetne a korábbiaknál 


\section{A bizalom kérdése}

Lengyelországban is megtörtént a korábbi magánnyugdíjreform reformja, ott is nagyrészt visszacsinálták azt, amit szinte egy időben Magyarországgal a kilencvenes évek vége felé elkezdtek. A pénztárak, a tagok vagyonának nagy része ott is visszakerült a társadalombiztosítás kezelésébe.

A tagoknak ilyen ellenreform esetén jelentősen csökkenhet a bizalma a hosszú távú megtakarítási intézményekben (és általában az intézményrendszerben). Pénztári vezetők, értékesítők igazolták vissza Magyarországon 2011 után azt az elterjedt vélelmet, miszerint „ha lehet egyszer államosítani, akkor lehet majd máskor is”, még ha az „államosítás” szó nem is feltétlenül pontos, bár kétségkívül elterjedt leírása a történteknek. Az önkéntes pénztári befizetések visszaesésére is hatott a bizalomvesztés (a kedvezmények csökkenése mellett), miután az átlagfogyasztó nemigen érti a két pénztár közti különbséget, és ha az egyiket „el lehetett venni”, akkor nyilván a másikat is.

A lengyel miniszterelnök a törvényjavaslat benyújtásakor külön kiemelte, hogy a lengyel magánnyugdíjpénztárakkal előállt helyzet nem ismétlődhet meg, „akkor az ország legfelsőbb bíróságai világosan deklarálták, hogy azok az eszközök közösségiek voltak, nem pedig magántulajdon. Most azonban a kezdetektől egyértelmü, hogy az új alapok a polgárok örökölhető magántulajdonát képezik”. Erre vonatkozóan egy új, ezt garantáló direkt szabályozás is került a törvénybe. Érdekes lesz majd figyelni, hogy mindez elég-e a magas arányú kilépések megelőzésére.

A fenti specifikus emlékekhez jöhet még a mi esetünkben a pénzügyi szektorral kapcsolatos bizalomvesztés is, brókerbotrányok és egyebek, és ami rájátszás még történt erre (büntetőadók a bankokra és egyéb pénzügyi közvetítőkre, „eltőzsdézték” a vagyont, stb.). Nem lehetetlen, de nem is nyilvánvaló, hogy az emberek ismét teljes bizalommal forduljanak egy új megtakarítási intézmény felé, amely évtizedekre előre gyűjtené a befizetéseket.

\section{A befektetések}

Térjünk rá a legrelevánsabb kérdésre: ki, milyen szabályok szerint, hogyan fekteti be a befolyó pénzeket? Nyilvánvaló, hogy ennek szabályozása és gyakorlati megvalósítása befolyásolja - a tagdíjak mértékén túl - elsősorban az ebből a pillérből nyerhető jövőbeli nyugdíjszínvonalat. A reform sikerét, az elért - illetve elmaradt - hozamokat a tevékenységnek és a költségeknek három szintje befolyásolja majd: (1) mennyit visznek el a díjak és költségek a befektetési eredményből, (2) milyen hatékonyságúak a befektetések a költségek számítása elött, és (3) mi a befektetések hasznosulása a gazdaság, a növekedés egésze szempontjából.
A bevezetőben hivatkozott korábbi írásomban igyekeztem ezeket a - reformot bevezetni tervező minden országban felmerülő - kulcskérdéseket részletesen kifejteni. Az új lengyel törvényt, a korábbiakban megvalósult brit, új-zélandi, török és egyéb idevágó szabályozásokat megvizsgálva, megerősítve láthatjuk, hogy a fö kérdés a governance, az, hogy ki dönt, hogyan dönt, mik a szempontok, mekkora a transzparencia, hogy a folyamatok elsősorban az ügyfelek érdekeit tartják-e szem elött. Másképp fogalmazva: lehetőleg se az állam, se a pénzügyi piacok partikuláris érdekei ne tudjanak az ügyfél érdeke, a minél magasabb időskori nyugdíjszínvonal elé kerülni.

Sehol nincs kolbászból a kerítés. Mindenhol vannak botrányok, részrehajlások, akár bünesetek. Az elit, a jobb módú gazdasági-politikai vezető réteg mindenhol igyekszik a maga érdekeit érvényesíteni. Valahogy mégis megállapítható, hogy akár a kisebb-nagyobb stikliket, trükközéseket, befolyásolásokat, akár a nagyobb ívű, társadalmi szinten elvarratlan ügyeskedéseket, színjátékokat egyes országok, országcsoportok inkább jellemzően hamarabb kivetik, kiharcolják magukból, míg más helyeken inkább tartósan fennmaradnak. Világunk sajnos úgy van berendezve, hogy az utóbbi helyekből van több.

Lehetőleg se az állam, se a pénzügyi piacok partikuláris érdekei ne tudjanak az ügyfél érdeke, a minél magasabb időskori nyugdíjszínvonal elé kerülni.

Ez persze egyáltalán nem nyugdíjrendszer-specifikus téma, hanem az együttműködésre, a jogkövetésre alapuló „ismétléses játékok” általános sajátja. Emiatt hosszú távon megbízhatóan működő, a társadalom nagy részének érdekeit szem előtt tartó intézmények hol jobban, hol kevésbé képesek tartósan fennmaradni egy-egy országban, rendszerben. De kicsiben idetartozik témánk is: ha már sikerül a munkavállalók jelentős részét - ismét - beterelni egy megtakarítási rendszerbe, az nekik vajon meg fogja-e érni a végén.

A lengyel esetben legalább három év tapasztalattal bíró helyi alapkezelők, biztosítók, nyugdíjalapok, korábbi foglalkoztatói nyugdíjalapkezelők kezelhetik majd a vagyont, akiknek egy állami irányítású Alapnál kell regisztráltatniuk magukat. A munkáltató kötelezett választani egyet közülük. Az ő alapjaikba kerül majd a pénz, és azt legalább 70 százalékban helyi (złoty) denominációjú eszközökbe kell fektetni. A kezelési díjat a vagyon 0,6 százalékában maximálják (amelynek egy része teljesítményfüggő díj lehet), ezen felül további legfeljebb 0,5 százalékot érhetnek el a tranzakciós, letétkezelési és egyéb adminisztrációs költségek. A megtakarítás a felhalmozási időszakban teljes mértékben örökölhető (illetve a fix időtartamra programozott lehívás esetében az esetlegesen hátramaradó részösszeg is).

A befektetések alapja a tag életkorától (nyugdíiig várható évei számától) függő életciklus-portfólió / céldátum alap lesz, amely az életpálya elején több, a végén kevesebb ingadozást, rövid 
távú kockázatot, részvénykitettséget ír elő, illetve tesz lehetővé. A tag ettől saját döntése alapján, bizonyos keretek között eltérhet. Továbbá a korábban már említettek szerint az összeg egy részéhez elöre szabályozott esetekben hozzá lehet majd férni, így a hosszú távú hozamoptimalizálás mellett ezekre a likviditási szempontokra is figyelemmel kell majd lenni.

A regisztrált nyugdíjalap-szolgáltatók nem utasíthatják vissza egyik munkáltatót sem, amely velük kíván szerződni. Bár a jogszabálytervezet szövege nem teljesen egyértelmű, valószínűleg differenciálhatják majd díjaikat (a cég mérete, a dolgozók száma alapján például), és a központi adatbázisból ennek ki kell derülnie. A nagyobb vállalatokért nyilván erősebb verseny lesz, de a kisebbek esetében sem léphetik túl a díjak és költségek a törvényben engedélyezett maximumot.

Ezen túlmenően egy további, elsőre szokatlan és nem pontosan értelmezhető elöírás is kiolvasható a törvényből. Eszerint ha egy szolgáltató kezelt vagyon alapján számított piaci részesedése meghaladja a 15 százalékot, akkor csak a 15 százalékig terjedő részre érvényesítheti a díjat, azaz arányosan csökkentenie kell a díjkulcsot. Ez a legmeghatározóbb szereplők díjbevételét maximálhatja, illetve serkentheti a piacot a kevés számú szolgáltatóból álló oligopólium elkerülésére. Megvallom, ez az előírás nem teljesen egyértelmű, és még ha a fentieket is takarja, akkor is kérdéses a hatása. Egyrészt a piacot arra „kényszeríteni”, hogy legyen legalább hét nagy szereplő, nem biztos, hogy paranccsal lehetséges, illetve a piaci szereplők kreativitása persze minden szabályozásból ki tudja hozni az optimumot. Másrészt a szolgáltatók száma és a piaci hatékonyság és díjszintek között messze nem egyértelmű az összefüggés, kevés szolgáltató mellett is lehet olcsó, sok szolgáltató mellett is lehet drága a müködés. Nem ezen múlik.

\section{Lehetséges irányitási, müködési modellek}

Viszont akkor min múlik? Alapvetően két módon jöttek létre vagy alakultak át nyugdíjmegtakarítási rendszerek a világban az elmúlt néhány évtizedben. Néhány országban felismerték, hogy a költségek csökkentésének és a működési hatékonyság növelésének az a legjobb eszköze, ha az operáció nagy részét, ahol a versenynek kevésbé, a mérethatékonyságnak viszont annál inkább van terepe, központosítva hozzák létre. Központi beszedés, számlavezetés, adminisztráció, informatika, nem pedig ugyanezek széttagolt megvalósítása. A verseny megmarad ott, ahol valóban értéknövelő lehet: a vagyonkezelés területén.

Ugyanakkor azt is felismerték, hogy itt is fontos mind a függetlenség és transzparencia, mind a költséghatékonyság. Ezért felértékelődött a kulcsszerepe azoknak az igazgatóságoknak, amelyek a meghatározóan nagy, esetenként központi szerepet játszó nyugdíjszolgáltató „elosztók”-at irányítják, és amelyek meghatározzák a hosszú távú befektetési politikát, és hozzá a legszélesebb merítéssel megversenyeztetik és kiválasztják a szolgáltatókat, alacsony intézményi díjazás mellett. A szolgáltatók, alapkezelők így nem közvetlenül az ügyfelekért (az egyénekért vagy a munkáltatókért) versenyeznek magas marketingkiadások mellett, hanem kizárólag a teljesítményükkel és tudásukkal a központi intézményi megbízásokért, azok egy részéért.

Ez részben nyilvánvalóan le tudja szorítani a költségeket és így emelni a nettó hozamokat. Másrészt, ha a döntéshozatali mechanizmus legalább annyira függetleníthető az állam beavatkozásaitól, mint az egyes piaci szereplők érdekeitől, akkor a hosszú távú bruttó befektetési teljesítmény is javítható.

A fenti leírás nagy részben tükrözi például az elmúlt tizenöt-húsz év svéd és brit reformjait. Számos más, a megtakarítási piacot javítani akaró ország szabályozói is figyelemmel követik ezeket a trendeket, de azután gyakran mégsem ezt valósítják meg.

Gyakrabban tapasztaljuk számos országban azt, hogy egy szegmentáltabb - és így operációs szempontból drágább - piac jön létre, amelyet a pénzügyi szolgáltatók erősebben uralnak. Az ügyféladatok óriási értéket jelentenek, ezeket értelemszerüen más termékek értékesítésére is hasznosítani tudják a pénzügyi csoportok. Így az egyedi/ csoportos ügyfélszerzési verseny fennmarad, és persze végül drágítja a terméket. A vagyonkezelés transzparens és teljesen költséghatékony megversenyeztetése ezek után kevésbé fontossá szokott válni.

A szolgáltatók közötti ilyen típusú verseny nehezíti azt is, hogy valóban hosszú távú, az ügyfelek nyugdíjcéljaival teljesen kompatibilis befektetési stratégiák kerüljenek megvalósításra. Ha egy erre szakosodott objektív és professzionális, „türelmes” központi igazgatótanács helyett az ügyfelek rövidebb távú impulzusai mozgatják a szolgáltatók között a vagyont, az alapkezelők rövidebb távra fognak optimalizálni. A korábbiakban említett, a lengyel esetben is alkalmazott életciklus portfólió előírások ezt a problémát valamelyest tudják kezelni, de messze nem tökéletesen.

Fontos szempont az is, hogy vajon egy teljesen új megtakarítási struktúra jön-e létre a semmiből, vagy egy már meglévő mellett/helyett nőne ki egy új, mint például egy várhatóan nagy volumeneket eredményező kváziönkéntes foglalkoztatói rendszer (vagy akár egy kötelezésre alapuló szisztéma). Gyakran tapasztalható, hogy a status quo a pénzügyi közvetítői rendszernek már nem elég jó (például mert alacsony szinten megrekedtek a tisztán önkéntes megtakarítások), ezért neki is érdeke az új rendszer, de persze csak úgy, ha a régi intézményi modell örökíthető át. Ezért is tipikus, hogy az állam és a szolgáltatók között olyan megegyezés születik, amely a közepesen hatékony struktúrát viszi tovább egy várhatóan jóval nagyobb méretü új piacra, cserében a szektor „vállalja” a díjplafonokat. Éppen ezt látjuk most a lengyel, nemrégiben a török és más esetekben is. 
A rendszer így persze jelentősen többe fog kerülni a fogyasztónak, a nyugdíjmegtakarítónak. Ahogy láttuk, a díjak teljes szintje meghaladhatja az egy százalékot. A svéd vagy a brit rendszer célja, hogy fél százalék alá csökkentse a teljes költségeket, és hosszú távon 0,2-0,3 százalékot céloznak meg. A kettő közötti különbség önmagában akár 10-15 százalékos különbséghez is tud vezetni a majdani nyugdíjszintekben. A piaci, irányítási modellek különbözősége miatt eleve ilyen hátránnyal indul például egy új lengyel szisztéma is, még ha nyilván van értelmes határa a költségek csökkentésének ${ }^{7}$, és nem csak a költségek számítanak, hanem a költségektől tisztított befektetési teljesítmény és folyamatok talán még inkább. Itt az egyik fontos összetevőre már az imént kitértünk: ha sok szolgáltató kínálatából választ egyet egy független (valóban független!) befektetési igazgatóság, avagy ha egyből egyet a pénzügyi szolgáltató, vajon várható-e hosszú távon különbség, esetleg előny az első javára?

A másik a befektetési szabályozás, a korlátok. Ezeknek csak egyike, de talán egyik legfontosabbika az a kérdés, hogy mivégre is hozza létre és támogatja az állam ezeket a hosszú távú megtakarítási rendszereket. Van-e más szempont, mint a majdani nyugdíjasok jóléte (és ezzel persze az állam majdani problémáinak mérséklése, ennyiben tehát „önérdek”)? Prioritás-e, cél-e emellett a hazai gazdaság fejlesztése a nehezen összeszervezett hazai megtakarításokból? Jólesik-e netán még az állam eladósodását is részben ebből a forrásból finanszírozni? Ezek a kérdések óhatatlanul merülnek fel szinte minden esetben, és a részrehajlást jellemzően nem sikerül elkerülni. Gyanítható, hogy az előttünk álló, a globalizáció eddig elért mértékéből visszavevő, bezárkózóbb, kereskedelmi háborús időszak behozhat új szempontokat a vagyonkezelési szakma és „tudomány” nemzetközi diverzifikációról kialakított nézeteibe is. Az eddig is jellemzően, sok helyütt fennállt túlallokáció a hazai befektetésekbe („home bias”) erősödhet, még több felső szintű gazdaságpolitikai támogatást nyerhet.

A lengyel szabályozás már az ő magánpénztári időszakukban is még a szokásosnál erősebben korlátozta, szinte teljesen kizárta a külföldi befektetéseket. Amint láttuk, az új szabályozás is legfeljebb 30 százaléknyi külföldi devizakitettséget tesz lehetővé, a megtakarítások túlnyomó többsége tehát lengyel állampapírokba és vállalati papírokba, részvényekbe és kötvényekbe kerül majd befektetésre.

Az élet úgy hozta, hogy több olyan fejlődő, felzárkózó országban volt alkalmam nyugdíjrendszereket közelről látni, ahol az állam úgymond privatizálta a piac egy részét, magán-nyugdíjbiztosítókra és nyugdíjszolgáltatókra bízta a megtakarítások egy részének gyűjtését és befektetését. Ugyancsak sort kerített a gazdaság, a vállalatok nagy részének privatizációjára, tőzsdei bevezetésére. Így vállalati, ágazati nyugdíjalapok, az államtól független piaci szereplők tudnak az államtól szintén függetlenné vált cégeket is finanszírozni.
Az esetek egy részében azután a történet valóban tartalmilag is így történt. Más esetekben azonban azt kellett megtapasztalni, hogy az összefonódások meglehetősen erősek maradtak, hogy meghatározó nagy konglomerátumok képesek önmagukat pénzelni, hogy az állam és a magángazdaság, politika és üzlet nem válik el teljes mértékben. A vagyonok kezelöi, még ha maguk nem is mindig ennek az összefonódó világnak szerves részei, akkor is - explicit vagy implicit - noszogatást érezhetnek arra, hogy ne csak a szigorúan vett befektetési fundamentumokat vegyék figyelembe döntéseik meghozatalakor.

Amikor a szabályozás az állam és a piac megegyezéséből alakul ki, és ráadásként erős korlátokat állít a hazain kívüli eszközökbe történő befektetések elé, a tapasztalatok szerint mindig nagyobb az esélye annak, hogy az ügyfél, a megtakarító érdeke nem kizárólag a költségek szintje, hanem a tőke félreallokációja miatt is sérülhet. Emiatt a bizalom korábban említett kulcsfontosságú kérdése vetődhet még erősebben fel. Érdemes lehet erre a lengyel felügyeletnek is figyelnie.

\section{HIVATKOZASOK}

'A PPK-ról letöltve 2018. szeptember 17-én

http://mondaq.com/x/725360/Employee+Benefits+Compensation/Draft+Of+The+Polish+Act+On+Employee+Capital+Plan ${ }^{2} \mathrm{~A}$ szejm 2018 . oktober elejên fogadta el a törvényt, a kézirat leadásának október 24 -i idő́pontjában a szenátus és a köztârsasági elnök jovahagyasa van még hàtra, lgy az nagy valoszintuseggel gyakorlatilag elfogadottnak tekintheto.

oltzer Péter: Egy kváziönkéntes nyugdij-előtakarékossági rendszer magyarországi szükségességérỏl és megvalósithatósá

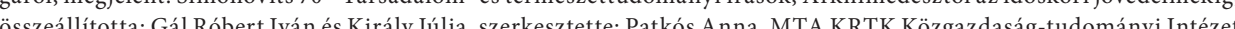
Budapest 2016. che

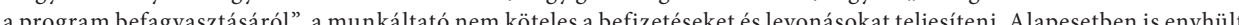
az elöírásokat nem betartó munkáltató elbírálása, büntetőjogi felelösségról egyszerü pénzbírságra.

"Az MNB 2018, évi ,Biztosítási, pénztári és tőkepiaci jelentée" szerint a munkáltatói befizetések aránya a 2007 évi 71\%-ról 2017-re 38\%-ra esett, és ez a csökkenés különösen 2011 után gyorsult fel. Az MNB-anyag a csökkenést a cafeteria-szabályok változása következtében megnövekedett adóterheknek tudjabe.

${ }^{6}$ Ez természetesen nem jelenti azt, hogy a kézirat leadasa és a megjelenés közti nehány hétben nem történhet valami. A

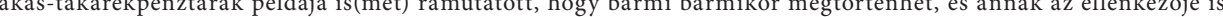
Igy azt sem tudhatjuk egyébként, hogy az ezzel egy idoben, az Allamadósság Kezelö Központ vezetójetol felreppen egymondatos utalas arrol, hogy az allam belépne a nyugdijmegtakaritások piacára, barmilyen modon köszönoovviszony ban lenne-e a cikkben leirtak

'Például nagyon érdekes lesz figyelni, hogy a világ egyik meghatározó alapkezelöje, a Fidelity által nemrég teljesen ingye-

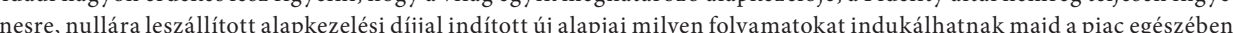

